\title{
Sustaining Sustainable Reforms for Vocational Legal Education in Nigeria: The Way Forward
}

\author{
Omoniyi Bukola Akinola, Ph.D \\ Department of Professional Ethics and Skills, Nigerian Law School, \\ Kano Campus, Bagauda, Kano State, Nigeria
}

\begin{abstract}
The Council of Legal Education is a major provider of vocational legal education to Nigerian legal market and beyond. In the years 2008 - 2009, the Council of Legal Education reformed its vocational legal education content in terms of developing and improving on the Curriculum and took other measures towards improving the quality of lawyers produced by the body. The methodology in this paper is based on literature review, classroom experiences in the course of implementing the reforms, and societal reactions from lawyers and feedbacks from consumers of legal services. This paper examined the role of the Council of Legal Education vis-à-vis providing vocational legal training to law graduates from the university and preparing aspirants to the Bar for presentation to the Body of Benchers for their formal call to bar and onward provision of legal service to the consumers in the legal market. The paper briefly considered the role of the Body of Benchers as critical stakeholder vis a vis the concept of fit and proper within the production chain for lawyers. The paper further dwelt on the various reforms for sustainable training by the Council of Legal Education. The paper also emphasised the various professional offences for which a lawyer who is reform - deficient may be sanctioned and exposes the law graduate to the reward systems and potentials embedded in the legal profession in the long run. The paper ends with steps to take towards sustaining and improving on the 2008 - 2009 reforms in vocational legal education under the supervision of the Council of Legal Education.
\end{abstract}

Keywords: Curriculum, School, Sustainable, Reforms.

DOI: $10.7176 / J L P G / 92-21$

Publication date: December $31^{\text {st }} 2019$

\section{Introduction}

The role of the Council of Legal Education in nation building cannot be over emphasised. This is because the Council of Legal Education is one of the chains in the manufacturing industry for production of lawyers to render legal services to the nation and the international community as the need arises. Legal education in Nigeria has a unique history. The paper briefly narrates the history of vocational legal education in Nigeria and states the conditions for admission into the Nigerian Law School. This paper will further examine the role of the Nigerian Law School vis-à-vis taking law graduates as raw materials from the university and training them for presentation to the Body of Benchers for formal call to bar and for onward transmission to the consumer of legal services. The paper will briefly consider the role of the Body of Benchers within the production chain of lawyers. The paper will further dwell on the various reforms for sustainable training at the Nigerian Law School. The paper also emphasised the various professional offences for which a lawyer may be sanctioned and exposes the law graduate to the reward systems and potentials embedded in the legal profession in the long run. The paper ends with steps to take towards sustaining and improving on the 2008 - 2009 reforms of the Council of Legal Education.

\section{History of Legal Education in Nigeria}

Pre - 1960, there were no structures for formal training of lawyers during the colonial administration. The Supreme Court Ordinance of 1876 provides that the Chief Justice shall have the power to approve, admit and enrol to practice as Barristers and Solicitors in the Courts such person as shall have been admitted in any of the Courts in London, Dublin and Edinburg. ${ }^{1}$ However, the Supreme Court Ordinance of 1876 made by the colonial government empowered the Chief Justice to appoint 'fit and proper' persons with basic education and some knowledge of English law and practice as local attorneys with renewable license to practice for six months on the condition that they exhibit good character during the period of legal practice. ${ }^{2}$ Legal education in Nigeria got a solid foundation from the Unsworth Committee recommendations of April, $1959 .{ }^{3}$ Prior to the constitution of

\footnotetext{
${ }^{1}$ Supreme Court Ordinance of 1876.

2 A. Alegeh, (SAN), 'Legal Education in Nigeria, Way Forward.' Fifty Years of Legal Education in Nigeria - Challenges and Next Steps. Nigerian Law School 1963 - 2013, Part IV, Chapter 13, pg 151 at 154.

${ }^{3}$ The Federal Government of Nigeria in April 1959 appointed a committee known as Unsworth Committee. The chairman of the committee was the Attorney General of the Federation known as Mr E.T.C Unsworth. The members of the Committee were the Solicitor General of the Federation,the Legal Secretary of the Southern Cameroon and 6 distinguished legal practitioners.
} 
the Unsworth Committee, some deficiencies were observed with respect to lawyers trained in England. The deficiencies of the English - trained lawyers are:

a) In England, he is trained as a barrister or a solicitor and after qualification he only practises there as such. In Nigeria, upon becoming a legal practitioner or on being called to the bar and enrolled at the Supreme Court he practises as both barrister and solicitor. In England a person can either be a barrister or a solicitor and he is trained to become either of them.

There were apparent lacuna and noticeable deficiencies in his training in England which are as follows:

i. In England, he studied English textbooks and Law Reports which authorities are merely of persuasive effect in Nigeria;

ii. The English trained legal practitioner has no knowledge of Nigerian customary law or essential part of our legal system. There is a seemingly lack of appreciation of our local laws e.g. Constitutional Law due to their foreign orientation;

iii. Almost all the practioners in Nigeria who had trained in England did not have University degree and did not take the post - call practical course nor were they attached to Chambers for mandatory one year Pupillage;

iv. There is lack of appreciation of our legal procedure in Nigeria;

v. The English trained lawyer also studied under the environment of unitary system of government and constitution whereas Nigeria practices the Federal system of Government.

Taking on the history of legal education is different from the history of legal profession in Nigeria. Virtually all the recommendations of the committee were on legal education in Nigeria. This is because legal education dovetails as the tap root of the legal profession while ethics reveals the stem, strength and beauty of the state of the tree of the legal profession. The Unsworth Committee recommendations were as follows:

1. Nigeria should establish its own system of legal Education .

2. That a Faculty of law should be established first at the University College Ibadan and subsequently at any other University to be established in future

3. A Law School to be known as the Nigerian Law School should be established in Lagos to provide vocational course for aspirants to the Bar.

4. The qualification for admission to legal practice in Nigeria should be a degree in law of any University whose course for the degree is approved by the Council of Legal Education and vocational course prescribed by the Council.

5. Any person graduating in Law from a University which has not accepted the syllabus recommended by Council of Legal Education (CLE) should be registered to take some further exam as the Council may prescribe.

6. A Council of Legal Education should be established.

Most of the recommendations were accepted and implemented by the government by virtue of the repealed Legal Education Act of 1962 and Legal Practitioners Act 1962. The Legal Education (Consolidation) Act 1976 was enacted to re-enact the Legal Education Act 1962 as amended up to date and to introduce new provisions relative to the composition of the Council of Legal Education and the appointment of the Director - General of the Nigerian Law School. ${ }^{1}$ Section 1(2) of the Legal Education (Consolidation) Act 1976 provides that the Council of Legal Education shall have the responsibility for the legal education of persons seeking to become members of the legal profession in Nigeria. The Council of Legal Education administers the Nigerian Law School. The Nigerian Law School was set up late 1962 and it ran its first 3 months Course for 8 students at a bulding acquired by the Council of Legal Education at 213 Igbosere Street, Lagos from January to April 1963. The graduates who had already been called to bar had to do 1 year course at the first year which started in October 1963. Pupillage was a compulsory part of the training of lawyers in the earlier part of legal education in Nigeria. Though, pupillage was not compulsory but necessary and highly needful because it exposes the new wig to experiential learning and saves the new wig from avoidable pitfalls in practice. Pupillage helps the new wig to have a mentor and learn through the ropes. Though, pupillage may not be economically viable from the beginning but has a good future and richer reward system. This is because learning is continuous. Rule 11 and 12 of Rules of Professional Conduct for Legal Practitioners 2007 provides:

\footnotetext{
${ }^{1}$ Section 1 of the Legal Education (Consolidation) Act Cap L10, LFN 2004.
} 
(1) A lawyer who wishes to carry on practice as a legal practitioner shall participate in and satisfy the requirements of the mandatory Continuing Professional Development (CPD) Programme operated by the Nigerian Bar Association.

(2) The activities in which a lawyer is required to participate for the purpose of the Continuing Professional Development Programme of the Nigerian Bar Association shall include:

(a) attendance and participation in accredited courses;

(b) lectures, seminars, workshops and conferences on law approved by the Nigerian Bar Association;

(c) writing on the law and its practice in books or journals and newspapers approved by the Nigerian

Bar Association;

(d) study towards professional qualifications approved by the Nigerian Bar Association; and

(e) other approved means of acquiring legal professional knowledge and experience.

Some of the conditions for admissions into the Nigerian Law School include being certified 'Fit and Proper' persons on the recommendation of the Head of the Faculty of Law of a University approved by the Council of Legal Education where the aspirant graduated from. Possession of Bachelor of Laws (LL.B) Degree Certificate approved by the Senate of the University recommending the applicant and transmitted to the Nigerian Law School as of the time the applicant seeks admission into the Nigerian Law School. Nigerian citizenship is no longer a compulsory requirement for admission into the Nigerian Law School. It is important to note that non Nigerians can now apply for Nigerian citizenship if they satisfy the conditions set out in section 25 of the 1999 constitution. The most important of these conditions is resident in Nigeria for a continous period of 15 years and assimilation of the way of life in that part of Nigeria where he is resident or he proposes to be resident.

Furthermore, non - Nigerians may be called to the Nigerian Bar in the following cases: Section 1 (b) of the Legal Practitioners Act 1992 provides that if such Nigerian citizen produces a qualifying Certificate to the Body of Benchers and shows that he is of good character, he may be called to the Nigerian Bar.

Secondly, where the Council of Legal Education grants dispensation, this is done by virtue of the Professional Bodies (Special Provisions) Act) 1992 and the Professional Bodies (Legal Profession) exemption Order 1973. The exercise of this power by the Council of Legal Education is no longer relevant following the provision of Section 1 (b) of Legal Practitioners Act 1992. The restriction is no longer of much value as non-citizen can now be enrolled.

Thirdly, the Attorney General of the Federation after consultation with the Bar Council and the Body of Benchers has made regulations providing for enrolment of Non- Nigerians who satisfy the following two conditions:

i. $\quad$ They are authorised to practise law in their own country.

ii. Their country accords the same privilege to Nigerians, the regulation may require the passing of prescribed examinations. ${ }^{1}$

\section{The Composition and Functions of the Council of Legal Education}

Having stated above that section 1 of the Legal Education (Consolidation, etc) Act established the Council of Legal Education, it is apposite to state its composition and functions towards attaining the essence of this paper. The Composition and functions are stated below.

\subsection{Composition}

The Council of Legal Education consists of the following members:

i. A Chairman to be appointed by the Federal Executive Council on the recommendation of the AttorneyGeneral of the Federation;

ii. Attorneys - General of the States, where there are no incumbent Attorney-General, the SolicitorGeneral of the States;

iii. The Head (Dean) of the Faculty of Law of any recognised university in Nigeria, whose course of legal studies is approved by the Council as sufficient qualification for admission to the Nigerian Law school;

\footnotetext{
${ }^{1}$ Section 7 (2) of the Legal Practitioners Act LFN 2004
} 
iv. The President of the Nigerian Bar Association;

v. Fifteen persons entitled to practise as legal practitioners in Nigeria of not less than 10 years post call and selected or elected by the Nigerian Bar Association;

vi. The Director-General of the Nigerian Law School; and

vii. Two persons who must be authors who published learned works in the field of law, to be appointed by the Attorney-General of the Federation.

3.2 Functions of the Council

a) Provision of legal education and training to aspirants to the Nigerian bar.

b) It administers the Nigerian Law School

c) It is saddled with the responsibilty of providing continuing legal education to legal practitioners.

d) It issues qualifying certificate to aspirants upon compliance with the requirements for call to the Nigerian Bar.

e) It recommends fit and proper persons (aspirants) to the Body of Benchers for call to the Bar.

f) It performs such other incidental matters in furtherance of the purpose of its establishment. ${ }^{1}$

The conditions for issuance of qualifying certificate by the Council of Legal Education are:

i. Nigerian Citizenship;

ii. Successful completion of course of practical training at the Nigerian Law School;

iii. $\quad$ Passing the Portfolio Assessment (oral examination on the externship experience);

iv. Eating of 3 dinner terms;

v. being fit and proper person in terms of good character.

\section{The Vision and Mission Statements of the Nigerian Law School}

One of the Vision Statement of the Nigerian Law School as stated in the new Curriculum of the School states: To maintain vocational training and capacity building for lawyers to be intellectually and professionally effective for meeting global challenges and ethical values. In the same vein, the first and second statements in the Mission Statement of the Nigerian Law School provide:

1. To educate and train law graduates in vocational skills that would enable them function optimally as barristers and solicitors;

2. To adopt skills-based, interactive and clinical methods of learning that would adequately prepare the graduates for their roles as lawyers to function as teachers, advocates, and solicitors, advisers, leaders in private enterprise and public service;

In furtherance of the above statements, part of the Mission Statements is to be a model Institution that aims to attain the highest standards of legal education and vocational training in the world; To train lawyers grounded in the ethics of the legal profession, who can respond to current national and international legal challenges in a diverse society, providing leadership in many different walks of life. Lastly, the Mission Statement entails maintaining vocational training and capacity building for lawyers to be intellectually and professionally effective for meeting global challenges and ethical values.

A careful perusal of the highlighted scope of the curriculum reveals that impartation of vocational skills is cardinal to both statements. The Federal Government should as a matter of urgency give all the necessary infrastructural support to the Council of Legal Education in view of the importance of the Nigerian Law School to nation building. The Nigerian Law School is one institution which solely provides the requisite manpower for the judicial arm of government. There is no other institution of learning in Nigeria or anywhere which single handed provides the needed manpower for a whole arm of government.

\footnotetext{
${ }^{1}$ For further reading, see Legal Education (Consolidation, etc) Act Cap L10, LFN 1990, s 1, 3 and 5 and O. B. Akinola,
} Principles of Law in Practice, (2nd Edn. St. Pauls Publishing, Ibadan, 2017) 23. 


\section{The Role of the Body of Benchers}

Section 3 of the Legal Practitioners Act 2004 established the Body of Benchers as a body corporate with perpetual succession and a common seal. The section provides that: There shall be a body of legal practitioners of the highest distinction in the legal profession in Nigeria to be known as "the Body of Benchers" which shall be responsible for the formal call to the Bar of persons seeking to become legal practitioners, and which shall consist of the following members, that is:

(a) The Chief Justice of Nigeria and all the Justices of the Supreme Court;

(b) the President of the Court of Appeal;

(c) the Attorney-General of the Federation and Minister of Justice;

(d) the Presiding Justices of Court of Appeal Divisions;

(e) the Chief Judge of the Federal High Court;

(f) the Chief Judge of the Federal Capital Territory, Abuja;

(g) the Chief Judges of the States of the Federation;

(h) the Attorneys - General of the States of the Federation;

(i) the Chairman of the Council of Legal Education;

(j) the President of the Nigerian Bar Association;

(k) thirty legal practitioners nominated by the Nigerian Bar Association; and

(1) Such number of persons, not exceeding ten, who appear to the Body of Benchers to be eminent members of the legal profession in Nigeria of not less than 15 years post-call standing.

For the sake of clarity, the functions of the Body of Benchers are listed below:

i. $\quad$ It is the body responsible for the formal call to Bar of aspirants.

ii. It prescribes call fees for aspirants to the bar

iii. It is the body saddled with the responsility of sponsoring aspirants to the Bar.

iv. It consults with the Nigerian Law School about the education of aspirants to the Bar.

v. It prescribes regulations for eating of dinners by aspirants to the Bar.

vi. It exercises disciplinary jurisdictions over erring legal practitioners and aspirants to the Bar.

For the purpose of elucidation, it is pertinent to state that upon completion of the practical course of training at the Nigerian Law School, each aspirant is duly sponsored in writing by the Body of Benchers and screened by the Council of Legal Education before their names are presented to the Body of Benchers for call to the Nigerian Bar.

Some other functions of the Body of Benchers include periodic prescription of what is fit and proper by way of sponsorship in writing of aspirants by 2 members of the Body of Benchers. It is the body statutorily empowered by section 3 of the Legal Practitioners Act for formal call to bar of qualified aspirants. The Body of Benchers is also empowered to issue Certificate of Call to Bar to qualified aspirants by virtue of section 4 (4) of the Legal Practitioners Act. Lastly, the Body of Benchers exercises disciplinary jurisdiction over members of the legal profession and aspirants seeking to become legal practitioners under section 10(1) (b) of the Legal Practitioners Act. To avoid identity crisis in the light of rise in the use of technology and threats to privacy data, passport photographs should be embossed in the Certificate of Call to Bar presented to qualified lawyers during the Call to Bar Ceremonies.

\section{The Concept of Fit and Proper at the Nigerian Law School}

By tradition, the role of a lawyer in every society is to be a servant of the laws, officer of the court and defender of the country's constitution together with its people. The public views lawyers as noble members of society who have the ability to rise above their self - interest in order to promote the rule of law and pursue the common good. ${ }^{1}$ Therefore, the lawyer must be above board and must exhibit high level decorum and candour in his dealings with persons he comes across in the course of life generally. Over the years, courts have however been confronted with cases where legal practitioners displayed outright greed at the expense of their clients. Such practises have brought about a loss of faith in the profession. ${ }^{2}$ The essence of being 'fit and proper' is to conform

\footnotetext{
${ }^{1}$ O. B. Akinola \& E. L. Effiong Expanding the Frontiers of the Concept of Fit and Proper in the Nigerian Law School. Submitted for publication in University of Benin Law Journal, Faculty of Law, University of Benin, Benin, Edo State, Nigeria (2019) (In Press).

${ }^{2}$ Charles Okike v LPDC (2005) 15 NWLR (Pt 949) 417; (2006) NWLR (Pt. 960) 67.
} 
to the ethics and traditions of the legal profession in order to exhibit the highest sense of integrity and candour in the discharge of their professional calling.

The Council of Legal Education has taken steps to ensure that students of the Nigerian Law School are diligent, possess integrity, honesty and a sense of responsibility by providing the Code of Conduct to guide the behaviour of students and rules for examination to maintain integrity of the examinations organised and conducted by the Council of Legal Education. Students are expected to comply with all the rules and regulations in that regard and where there is breach of any of the rules set out, such an offender will be disciplined accordingly. To this end, every student of the Nigerian Law School is given a Code of Conduct at the registration point upon gaining admission into the School. The School has prescribed certain conditions which its students must satisfy in order to qualify for call-to-bar. There are many standards expected of an aspirant to the Bar. Some of these standards of ethical behaviour are reproduced below:

a) The student must have participated in the mandatory three dining terms at the Law School;

b) The classes are mandatory and a student must attend at least $75 \%$ of the classes to be eligible to sit for the exams.

c) Every student must be attired in a proper and dignified manner.

d) Students must not generate nuisance in the School premises.

e) Students must not be a member of any cult or proscribed organisation);

f) Students are expected to maintain order in every gathering such as classes, group meetings, dinners, presentations in class, etc.

Students shall not be rude or molest or intimidate or harass any staff of the Nigerian Law School or fellow students nor engage in habitual drunkenness, use of foul language, admission into the Nigerian Law School through fraudulent means, engagement in secret brawling and other vices. The list is endless and this paper suggests that the list of acts codified as unfit and improper for aspirants to the bar should include proven cases of cybercrimes, internet fraud, reckless use and abuse of the social media by any aspirant to the Bar. In Okonjo v Council of Legal Education ${ }^{l}$ the Court held that the Council of Legal Education enjoys incidental powers by virtue of section 2 (5) of the Legal Education Act to prescribe further requirements for admission into the Nigerian Law School and this include good conduct.

It should be noted that being 'fit and proper' is a universal concept. In South Africa, admission to the profession of advocate is regulated by the Admission of Advocates Act 74 of 1964 (as amended). The Act prescribes in section 3 that an applicant should be older than 21, be a "fit and proper" person and have the right academic qualifications. In South Africa this means a Baccalaureus Legum (LLB) degree or an international qualification similar to an LL.B. The applicant should also be a South African citizen or a permanent resident and his or her name may not be on the Roll of Attorneys. In the final instance, it is up to the court to decide if a person is "fit and proper" to be allowed into the profession. Section 15 of the Attorneys Act 53 of 1979 prescribes similar general requirements for an applicant who wants to become an attorney. The court may enrol an applicant to the attorneys' profession only if "such a person, in the discretion of the court, is a fit and proper person to be so admitted and enrolled". Section 7 (1) (d) of the Admission of Advocates Act authorises a court to remove an advocate from the Roll of Advocates, if the court "is satisfied that he is not a fit and proper person to continue to practise as an advocate". Section 22 (1) (d) of the Attorneys Act states that a practising attorney may be struck off the Roll if that attorney "in the discretion of the court, is not a fit and proper person to continue to practise as an attorney". ${ }^{2}$

In the State of California in the USA, law students should begin the application process not later than the beginning of their last year of law study. Early filing is encouraged so that the process can be completed before results from a particular examination are released. Thereafter, State Bar staff review each applicant's history. Those with serious issues are referred to the Committee of Bar Examiners for consideration. The application is a compilation of many details of your life, including recommendations and references from present and former employers, fingerprints, Criminal convictions, drugs and alcohol abuse, debt and violations of schools' honour

${ }^{1}$ FCA/L16/Digest of Appeal Cases 28.

${ }^{2}$ O. B. Akinola \& E. L. Effiong Expanding the Frontiers of the Concept of Fit and Proper in the Nigerian Law School. Submitted for publication in University of Benin Law Journal, Faculty of Law, University of Benin, Benin, Edo State, Nigeria (In Press). 
codes. It is important to be honest in providing required information in the application process. The Committee of Bar Examiners considers candour to be a significant factor in determining whether an applicant has the good moral character required for admission to practice law. ${ }^{1}$

In the Ontario Bar in Canada, the Licensing Process for aspirants to the Bar requires that, to be eligible for call to the bar, all candidates must: have successfully completed all components of the Licensing Process as required, have paid all Law Society fees, including the call to the bar fee, have filed the required documents, be of good character, as required by section 27(2) of the Law Society Act. Candidates have a continuing obligation to keep the responses to the questions set out in the Good Character Section of their Application current, complete and correct prior to the date of call and have submitted all the required call to the bar related documents.

Despite all the commendable efforts of the Council of Legal Education, it is however worrisome to note that there is a sharp decline in the moral quality of some lawyers seen on the field. There is also the astronomical rise in the number of petitions received by the Body of Benchers through the Legal Practitioners Disciplinary Committee (LPDC) as are published in the Dailies periodically.

\section{Professional Offences in the Legal Profession in Nigeria}

There are recognized professional offences for which a legal practitioner may be sanctioned. ${ }^{2}$

These offences are:

a) Infamous conduct in a professional respect. It is instructive to note that infamous conduct in any professional respect is not defined in the Act. For instance, embezzling a client's fund can be classified as infamous conduct in a professional respect. Divulging client information with respect to a brief to purchase a property for the client and using the same information to outsmart the client through insider dealing is a breach of the duty owed to the client by the lawyer. In effect, the lawyer has taken advantage of information acquired during the handling of a client's case. The lawyer has failed to deal honestly with the client's property. ${ }^{3}$

b) Conducts incompatible with the status of a legal practitioner by virtue of section 12 (b) of the Legal Practitioners Act. For instance, eloping with a client's wife or being in a drunken state to stupor and falling inside the gutter diminishes the status of a legal practitioner. Street fight is also incompatible with the status of a legal practitioner.

c) Obtaining enrolment by fraud. For instance, where a Legal Practitioner engaged a proxy to write his School Certificate or matriculation examinations to gain admission into the university.

d) Conviction by any court in Nigeria having power to award imprisonment for an offence which is incompatible with the status of a legal practitioner. The offence in question must in the opinion of the LPDC be incompatible with the status of a legal practitioner. It is opined that these incompatible offences may exclude traffic offences or minor breach of environmental regulations. ${ }^{4}$

In order to avert these vices, it is apposite for the legal practitioner to imbibe the qualities which enable him succeed in his profession. These qualities are: Honesty and integrity in line with Rule 23 of the Rules of Professional Conducts for Legal Practitioners 2007 and the admonition of the court in the case of Adewumi v. Plastex (Nig) Ltd

It is apposite to state that hard work, determination and commitment are qualities expected of a legal practitioner in line with Rule 14 of the Rules of Professional Conducts for Legal Practitioners 2007.

\footnotetext{
${ }^{1}$ Ibid

${ }^{2}$ Legal Practitioners Act Cap L11, LFN 2004, s 12.

${ }^{3}$ Charles Okike v LPDC (2005) 15 N.W.L.R. (Pt. 949) 417; (2006) N.W.L.R. (Pt. 960) 67.

${ }^{4}$ O. B. Akinola, Principles of Law in Practice, (2 ${ }^{\text {nd }}$ Edn. St. Pauls Publishing, Ibadan, 2017) 146.

${ }^{5}$ [1986] 17 NSCC 852. The court in this case laid emphasis on the need for a lawyer to act honestly and conscientiously towards his client without prejudice to his role as a minister in the temple of justice. The court reminded legal practitioners of the need not to be the mouthpiece of his client to spew out anything dictated by the client but in line with his oath and Rules of Professional Conduct.
} 
In professional offences, the Nigerian Bar Association plays the role of an investigator through the Disciplinary Committee of the Nigerian Bar Association. One of the bodies which are empowered to sanction erring legal practitioners is the Legal Practitioners Disciplinary Committee. ${ }^{1}$ Section 13 of the Legal Practitioners Act also empowered the Chief Justice of Nigeria and the Supreme Court to sanction erring legal practitioners.

\section{The Nigerian Law School as the Bridge between the Aspirants and the Bar}

The Council of Legal Education serves as the entry point into the legal profession. The Legal Practitioners Disciplinary Committee is the exit point and the Supreme Court is the departure hall by way of Appeal in unsuccessful cases. The School receives aspirants as raw materials with knowledge of substantive law from the various Universities and train them in preparation for service in the legal market. The Nigerian Law School plays a critical role in final stage of preparing aspirants for enrolment at the Supreme Court. The 5 modules for the Bar Part II course are solid foundations for the procedural training of aspirants to the Bar.

The root for diversifying legal practice areas shoots from the Universities and the Nigerian Law School. Some of the practice areas which young aspirants and new wigs may be interested in are Sports law, Arbitration, Competition/Antitrust law, Electricity/Energy law, Legal Education, Corporate Law Practice, Legal consultancy and training services, Family and Child Rights Advocacy, Maritime/Shipping law, Law of Taxation, Conveyancing/Property law, Human Rights Law and Public Advocacy/Non - Governmental Organisations' among others.

\section{The Training Component at the Nigerian Law School}

This paper will delve into the basic training components for aspirants at the Nigerian Law School. As stated earlier in this paper, there is a Curriculum for the training of aspirants to the Bar. The Curriculum of the Nigerian Law School entails training of foreign students for the Bar Part 1 examinations and further training of students who obtained their LLB certificate in a University in Nigeria. By foreign students, we mean students who studied law outside the shores of Nigeria and whose course of study is in line with recommended law courses as approved by the Council of Legal Education. In the Bar Part II programme, attendance at lectures must be with $75 \%$ compliance on the part of aspirants to the Bar. The students are usually grouped for the purpose of moot and mock trial training and live presentations before sitting judges of High Court invited for the purpose by the Nigerian Law School. This inculcates the needed advocacy, drafting and research skills into students who participate in the training. Upon completion of 20 weeks of coursework, the student is exposed to further training after the course work as he proceeds on Court and Law Office externship placement. $^{2}$

The duration is 6 weeks for the Court attachment and 8 weeks in law firms approved by the Council of Legal Education. The Externship Training Component enables the externs to interface with the field supervisors who are judges, Magistrates, senior lawyers, administrators and court officials. There is a feedback mechanism through the students' Portfolio Assessment which is an oral examination before a panel of internal and external examiners on the experiential learning from the externship field. Confidential reports are submitted by the extern on their eligibility for call to the bar from their field supervisors. This is a peer review mechanism policy invented by the management of the Nigerian Law School post - 2009 to weed out potential bad eggs from aspiring to the Bar. A student who fails the Portfolio Assessment shall not be called to the bar though he succeeds at the Bar Final Examinations. The student will be made to repeat in full, the externship programme and successfully re-assessed for the Portfolio Assessment before his name is sent to the Body of Benchers for call to the Bar. The recent reform at the Nigerian Law School retained the 20\% Multiple Choice Questions out of the $100 \%$ marks per course in the Bar Examinations. The number of subjects an aspirant is required to pass is now 5 in lieu of 6 which was obtainable in the past. The Law of Evidence which is usually taught in the 4th year in the LL.B programme has been collapsed into Criminal Litigation and Civil Litigation as applicable.

\section{Recommendations towards sustaining the Current Reforms of the Council of Legal Education}

Some of the reforms in the Nigerian Law School after the advent of the multi - campus structure include a review of Curriculum of the School, designing lesson plans for each module, introduction of the Portfolio Assessment and introduction of feedback mechanism for field supervisors during the students' externship placement, introduction of team teaching by lecturers. In order to improve the quality of students being admitted

\footnotetext{
${ }^{1}$ Legal Practitioners Act LFN 2004, s 11.

${ }^{2}$ Nigerian Law School: Curriculum and Lesson Plans, 2014 - till date.
} 
to the Nigerian Law School, it is suggested that an entrance examination must be set by the Nigerian Law School for persons seeking admission into the School. The core subjects suggested to be tested should include Use of English Language, Communication Skills, Basic Ethics and Etiquettes expected of a Law Student, Principles of Drafting and Letter Writing.

In furtherance of the above, the Curriculum of the Nigerian Law School must be updated especially in terms of the Course content to capture changes in procedural and substantive laws as may be enacted periodically by the National Assembly. An example is the Administration of Criminal Justice Act and the various rules of courts across various jurisdictions.

A further review of the curriculum to allocate more time to moot trials and assess students in this respect should be looked into by the management of the Nigerian Law School. More judges of the High Court across different jurisdictions within Nigeria should be invited to preside and impart knowledge on aspirants to the bar. In the light of this, a minimum of 20 moot courts should be built by the Federal Government and donor agencies in each campus of the Nigerian Law School.

Teaching and non - teaching staff at the Nigerian Law School should be further motivated by way of exposure to periodic training within and outside Nigeria to learn new art of imparting legal skills in their students and improve administrative sagacity in service delivery to students and other stakeholders as consumers of legal education in line with international best practices in providing vocational legal education. This is buttressed in the words of Ekanem when he opined that: At present there is a paradigm change in world order. International boundaries seem to be gradually disappearing, traditional markets are melting into a global one, driven by electronic-transactions; and cash economy is fast giving way to a virtual one. Therefore the need arises for the 21 st century lawyer to continuously update his knowledge. ${ }^{1}$ In essence, the trainer should be trained to prepare the next generation to confront evolving societal transactional challenges in the legal market and economy at large.

In furtherance of the above in respect of staff motivation and career progression, the Council of Legal Education should invoke his powers in section 2 (5) and section 6 of the Legal Education (Consolidation, etc) Act 2004 to change the nomenclature of law lecturers at the Nigerian Law School to include Professors, Associate Professors in lieu of Directors and Deputy Directors of Academics as it is currently obtainable. It is further suggested that the requirements for attaining these career ranks should be as it is obtainable in Federal Universities in Nigeria in line with section 6 of the Legal Education (Consolidation, etc) Act LFN 2004. Expertise in core modules being taught by the law lecturer should be a core requirement.

Law lecturers should be encouraged to pursue their Doctorate degrees in areas applicable to modules being taught in the Nigerian Law School. Doctor of Philosophy in Laws should be a value addition to the Nigerian Law School. This will have a multiplier effect on the quality of specialised knowledge and skills being imparted into aspirants to the Bar.

There must be total infrastructural overhaul of teaching and non - teaching facilities across all the Campuses of the Nigerian law School. In this respect, funding from government and private sector is suggested. According to Ajogwu, inadequate facilities for use by aspirants and teachers have thwarted extensive research abilities capable of breaking new legal grounds. ${ }^{2}$ Nigeria was recently ranked 152 out of 157 countries in the World Bank's Human Development Index. In the words of Dr. Jim Yong Kim, the President of the World Bank Group, Nigeria, like many other African nations, was in the red zone because the country's health and education budgets were too low. His words, Africa needs to invest massively in education. ${ }^{3}$ Use of information technology in this era is vital to legal training. Internet services should be provided throughout the session for staff and students of the School.

In order to sustain and improve on the current reforms at the Nigerian Law School, the problem of understaffing should be tackled urgently by the relevant government agencies. For instance, teacher - student ratio should be improved upon. Each of the modules requires supervision by the law teacher during small group session

\footnotetext{
1 Etafia E. Ekanem, Legal Education, Lawyering and Ethics: Coasting through Turbulent Times. Available at www.unimaid.edu.ng. Accessed 21 November, 2019.

${ }^{2}$ Ajogwu Fabian, (SAN), Rethinking Legal Education in Nigeria to meet the Needs of the 21st Century. Being A paper presented at the Dinner held in honour of Chief Emeka Ngige (SAN) on his appointment as the Chairman, Council of Legal Education on Thursday, August 29, 2019 at Metropolitan Club, Kofo Abayomi Street, Victoria Island, Lagos. P. 5 ${ }^{3}$ ibid
} 
discussion. A situation where 2 law teachers monitor over a thousand students is no longer a small group and has defeated the essence of having to impart legal skills to students at micro level. It is not an easy task and almost practically impossible for 2 law teachers to properly debrief and get the proper assessment feedbacks from students on the knowledge imparted for the day's work.

In the light of the above, it is also a major challenge for 2 law teachers assigned to teach a module to adequately assess students' assignments where the population of the students exceeds 300 . There is no campus of the Nigerian Law School with a student population that is less than 300. Adequate staff strength will strengthen the reform and achieve the objectives behind it.

In order to further sustain the on-going reforms at the Nigerian Law School, there must be inter - agency collaboration towards reaching a common goal in service delivery. Funding institutions such as Tertiary Education Fund (TETFUND) should relax administrative bottlenecks and contribute their quota towards building modern facilities such as hostels, lecture rooms, libraries and Moot Courts for the Nigerian Law School.

\section{Conclusion}

For the prepared, the Nigerian Law School prepares an aspirant for a robust legal practice experience. There is a reward system for the hard working aspirant to the Bar. Nigeria is blessed with a population of over 180 million people out of which a good percentage will need legal services at one stage of their life and another. The reward system promotes conferment of the prestigious rank of Senior Advocate of Nigeria by virtue of section 5 (3) of the Legal Practitioners Act to core advocates and academics who have contributed immensely to development of jurisprudence, advocacy and legal scholarship. Appointments into the Bench are usually for the deserving and the morally upright. Young advocates with vision for the academia can rise to the peak of their career in academics as Professors of Law. Solicitors with flair for the corporate and commercial sectors should attain the level of providing core Company Secretary and legal advisory services. Alumni of the Nigerian Law School are into politics and have been appointed into various political offices in the past and currently serving the nation. With the above, it is safe to conclude that the Nigerian Law School fertilizes the spermatozoa and eggs as prepared by Nigerian Universities for further carriage and delivery into the labour room of legal practice in Nigeria and beyond. It is in the light of these invaluable contributions by the Council of Legal Education that the recommendations for sustaining sustainable reforms as suggested in this paper should be implemented in line with global best practices. The role of the Council of Legal Education in seeing the above to fruition cannot be over emphasised. The vocational training of lawyers should see into the future of the business world in quality and content. 